(c) American Dairy Science Association, 2004.

\title{
Variances of and Correlations Among Progeny Tests for Reproductive Traits of Cows Sired by Al Bulls
}

\author{
J. S. Clay, B. T. McDaniel, and C. H. Brown \\ Department of Animal Science \\ North Carolina State University, Raleigh 27695-7623
}

\begin{abstract}
Estimates of daughter fertility were computed using first artificial insemination (AI) breedings reported to the US Dairy Herd Improvement Association (DHIA) from 1995 through 1997. An animal model was used to compute estimated breeding values (EBV) of daughter groups with fixed effects of herd-year-month bred and classes of early lactation energy-corrected milk, days in milk (DIM) when bred, and parity. Standard deviations and ranges of bull EBV for daughter fertility for DIM were 9.1 and -31 to 18 ; standard deviations and ranges of bull EBV for daughter fertility for nonreturn were 3.8 and -11 to 10 . Correlations were computed for EBV for daughter fertility with EBV for mating bull fertility and with predicted transmitting abilities (PTA) for milk, somatic cell score (SCS), and productive life for bulls (213) with minimums of 200 matings and 100 progeny with reproductive traits. None of the correlations among EBV for reproductive traits differed from 0.0. Correlations of EBV for daughter fertility with PTA for productive life were significantly positive. PTA for yield traits were not correlated with EBV for daughter differences in nonreturn or DIM. Very low correlations of EBV for daughter reproductive traits with PTA for yield indicate that, in order to improve daughter fertility, fertility must be incorporated in sire selection decisions.
\end{abstract}

(Key words: daughter, reproduction, fertility, nonreturn)

Abbreviation key: $\mathbf{C I}=$ calving interval, DIM1 = days in milk at first AI mating, DIM1-S = EBV of sire for days in milk at first AI mating, ECM = summit daily early-lactation energy-corrected-milk, ERCR-S = estimated relative conception rate of sire or EBV for rate of nonreturn in $70 \mathrm{~d}$ for first AI mating, ERCR-MB = estimated relative conception rate of mating bull or the difference from average AI mating bull of herdmates

Received August 29, 2002.

Accepted December 5, 2003.

Corresponding author: J. S. Clay; e-mail: john_clay@ncsu.edu. for rate of nonreturn in $70 \mathrm{~d}$ for first AI mating, $\mathbf{N R 7 0}=$ nonreturn in $70 \mathrm{~d}$ to first AI mating.

\section{INTRODUCTION}

Reproductive efficiency has been documented to decline in the US dairy industry. Specifically, Butler (1998) reported a 25-point decline in first-service conception rate from 1951 to 1996 in New York, and Silvia (1998) reported an increase in services per conception of 1.62 to 2.91 from 1972 to 1996 . If accurate measures of daughter fertility were available, dairy producers could use them when selecting mating bulls to increase lifetime yield, reduce length of calving intervals, shrink the cost of additional inseminations, diminish the cost of intervention, and reduce culling for reproductive reasons. Selection decisions that use appropriate weighting of fertility traits with yield and milk quality could help improve overall profitability of the dairy herd. Historically, dairy fertility measures have been either traits of intervals, such as calving interval, days to first mating, or days to successful mating, or rates of success of breeding, such as services per conception or nonreturn. de Jong (1997) suggested that both nonreturn rates to first insemination and number of days to first insemination of daughters should be included in an index to most effectively identify a bull's ability to sire cows that are more fertile.

Although heritability and repeatability estimates for female reproductive traits were shown to be low several years ago (Berger et al., 1981; Hansen et al., 1983; Seykora and McDaniel, 1983; Ron et al., 1984; Hermas et al., 1987; Faust et al., 1989; Hayes et al., 1992; Weller and Ron, 1992; Marti and Funk, 1994; Boichard and Manfredi, 1994; Dematawewa and Berger, 1998), it seems that the changes in reproductive parameters in the dairy industry should be affirmed to prevent reliance on potentially inaccurate estimates during the computation of fertility measures.

The objectives of this study were to affirm earlier estimates of heritability and repeatability for female reproductive traits and to determine the variation in EBV for days in milk at first AI mating (DIM1) and nonreturn rates at $70 \mathrm{~d}$ (NR70) to first AI inseminations 
of lactating progeny groups sired by AI Holstein bulls. Correlations of EBV for fertility traits with estimated relative conception rates (ERCR-MB) of the same bulls as mates and with PTA for milk, SCS, and productive life were also examined.

\section{MATERIALS AND METHODS}

\section{Data}

First AI records from 1995 through 1997 for Holstein cows were obtained from herds participating in US DHIA. Data were restricted to first breedings, cows bred between 15 and $365 \mathrm{~d}$, breedings from lactations when DIM for the third milk recording day were less than 150, daily milk yields between 4.5 and $109.0 \mathrm{~kg}$, fat and protein percentages for each milk recording day between 2.0 and 8.0, and a minimum of 2 milk recording days within the first 3 with fat and protein percentages present. Breedings to virgin heifers and breedings to mates that left the herd prior to $70 \mathrm{~d}$ postinsemination were eliminated.

Herd edits required a minimum of 10 AI breedings within a year to exclude herds with either little information or incomplete data reporting. To eliminate breedings from herds that might have reported only successful inseminations, a herd's average conception rate could be no greater than $62.5 \%$. Although it is possible for herd managers to obtain valid conception rates greater than $62.5 \%$, these herds were indistinguishable from herds that did not report all breedings or herds that selectively reported breedings. A conception rate of $62.5 \%$ equates to 1.6 services per conception and eliminated $8.4 \%$ of possible herds. Daughter breedings were included only for sires with a minimum of 30 daughters in 1995 to 1997, inclusive. For the data set used to compute EBV for daughter fertility, only records from cows with legitimate dam identity were used. After edits, 694,704 cows with 760,525 first breeding records were in 255,694 herd-year-months for the 3-yr period. The mean first breeding nonreturn rate was $54.2 \%$, and the standard deviation was 48.4.

Reproductive performance was evaluated for DIM1 and NR70. A first breeding was deemed successful if a cow was not reported in heat or rebred within $70 \mathrm{~d}$.

The numbers of daughters in each of 14 states that contributed the most matings are listed in Table 1. Table 1 also illustrates that the average nonreturn rates by state ranged from $37.6 \%$ in Florida to $56.7 \%$ in Michigan.

The data from 40 states were divided into 4 sets of approximately 25,000 breedings for the computation of variance components, heritabilities, and repeatabilities. Records were included only for cows with unique sire and dam identities. Breedings from the complete

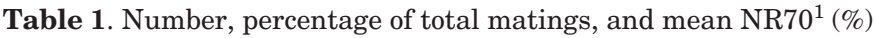
by state.

\begin{tabular}{lrcl}
\hline State & Matings & Percent & NR70 \\
\hline Wisconsin & 159,115 & 20.9 & 55.0 \\
New York & 152,771 & 20.1 & 54.3 \\
Pennsylvania & 56,283 & 7.4 & 51.4 \\
Virginia & 50,750 & 6.7 & 50.7 \\
Texas & 32,076 & 4.2 & 42.4 \\
Vermont & 31,716 & 4.2 & 52.5 \\
Iowa & 25,658 & 3.4 & 56.4 \\
Indiana & 21,852 & 2.9 & 53.9 \\
North Carolina & 18,700 & 2.5 & 48.4 \\
Michigan & 17,851 & 2.3 & 56.7 \\
Florida & 16,694 & 2.2 & 37.6 \\
Tennessee & 16,037 & 2.1 & 52.4 \\
Missouri & 15,655 & 2.1 & 54.6 \\
Illinois & 15,301 & 2.0 & 55.8 \\
Other 26 states & 130,066 & 17.1 & 50.3 \\
Total/average & 760,525 & & 52.4 \\
\hline
\end{tabular}

${ }^{1} \mathrm{NR} 70=$ Nonreturn in $70 \mathrm{~d}$ to first AI mating.

data set were assigned to sets according to the last 2 digits of their DHIA herd code: National US 1 (last 2 digits $=00,10,20)$ and National US 2 (last 2 digits $=$ $30,40,50$ ). Breedings from the southeastern states of Alabama, Florida, Georgia, Louisiana, Mississippi, North Carolina, South Carolina, Tennessee, and Texas were assigned according to the last digit of their DHIA herd code to sets Southeastern US 1 (last digit $=0$ through 4) and Southeastern US 2 (last digit $=5$ through 9). Although there was commonality between the National US 1 and Southeastern US 1, other data sets were independent. Breedings from herds with other herd codes were not used in the determination of variance components, heritabilities, or repeatabilities.

The data sets from the southeastern states enabled the identification of differences in genetic parameters caused by the stress of increased heat and humidity typically associated with the southeastern United States, and this stress has been found to depress reproductive activity and efficiency in dairy cows. Heat stress has been found to cause a reduction in the following factors contributing to a successful reproductive program: duration of estrus (Wolfe et al., 1974), conception rate (Badinga et al., 1985), and early embryonic survival (Guazdauskas et al., 1973; Thatcher, 1974; Roman-Ponce et al., 1977).

The PTA for productive life (PTA-PL) is a prediction of "time in the milking herd before removal by voluntary culling, involuntary culling, or death" (VanRaden et al., 1995) and is a prediction of herd longevity. Although PTA-PL does not include an explicit component for fertility, daughters of bulls with higher PTA-PL are probably more fertile than their herdmates. Correlations between PTA-PL, after adjustment for PTA-Milk and PTA-SCS, and the 2 predictions of fertility, EBV of sire 
for DIM at first AI mating (DIM1-S) and estimated relative conception rate of sire or EBV for rate of nonreturn in $70 \mathrm{~d}$ for first AI mating (ERCR-S), were tested for significant differences from zero.

Because producers currently use several traits in sire selection decisions, a couple of additional traits to improve fertility could both dilute emphasis on primary traits and confuse selection decisions. An index used in The Netherlands as described by de Jong (1997) combines effects of both days to first mating and nonreturn rate to produce a prediction of calving interval (CI). This index was adopted to use DIM1-S and ERCR-S to predict a difference in CI and was computed as:

$$
\begin{aligned}
& \text { CI Index (difference in days })= \\
& \text { DIM1-S (difference in days) } \\
& -0.4 * \text { ERCR-S (\% difference) }
\end{aligned}
$$

\section{Models}

Model 1 for nonreturn to first mating in $70 \mathrm{~d}$. A multiple-trait canonical transformation program (Misztal, 1990) was used in a single-trait analysis on the 4 sets to establish variance components for each trait. The animal model simultaneously adjusted for the effects of cows and their ancestors on nonreturn rates in $70 \mathrm{~d}$, while considering the effect of the mating bull on cow fertility.

Preliminary least squares analysis using the PROC GLM option of SAS (SAS, 1990) found no significant interaction effects among fixed effects; therefore, interactions were not included in either model.

The model for computing ERCR-S was:

$$
\begin{gathered}
\mathrm{NR70}_{\text {ijklmno }}=\mathrm{HYM}_{\mathrm{i}}+\mathrm{ECM}_{\mathrm{j}}+\mathrm{P}_{\mathrm{k}}+\mathrm{DIM}_{1} \\
+ \text { Animal }_{\mathrm{m}}+\mathrm{MB}_{\mathrm{n}}+\mathrm{PE}_{\mathrm{o}}+\mathrm{e}_{\mathrm{ijklmno}}
\end{gathered}
$$

where

$$
\begin{aligned}
\mathrm{NR70}_{\mathrm{ijklmno}=} & 70 \mathrm{~d} \text { nonreturn status of cow }(1 \text { if no } \\
& \text { return, } 0 \text { if bred again }) \\
\mathrm{HYM}_{\mathrm{i}}= & \text { herd-year-month of breeding, } \\
\mathrm{ECM}_{\mathrm{j}}= & \text { summit daily early-lactation energy- } \\
& \text { corrected-milk, } \\
\mathrm{P}_{\mathrm{k}}= & \text { parity } \\
\mathrm{DIM}_{1}= & \text { days in milk at first AI } \\
\mathrm{Animal}_{\mathrm{m}}= & \text { random effect of animal including ad- } \\
& \text { ditive relationships of } 2 \text { generations } \\
\mathrm{MB}_{\mathrm{n}}= & \text { AI mating bull, } \\
\mathrm{PE}_{\mathrm{o}}= & \text { permanent cow effect (uncorrelated } \\
& \text { random effect), and } \\
\mathrm{e}_{\mathrm{ijklmno}=} & \text { residual. }
\end{aligned}
$$

Using herd-year-month instead of seasons of longer duration allowed the model to account for changes in environmental effects that occurred within a short period of time in a herd or group. The model accounted for the effect of negative postpartum energy balance on milk yield by the use of daily energy-corrected milk (ECM) that was computed as:

$$
\begin{gathered}
\text { Energy-corrected milk }(\mathrm{kg} / \mathrm{d})=0.3246 \\
\times \text { milk }(\mathrm{kg} / \mathrm{d})+12.86 \times \text { fat }(\mathrm{kg} / \mathrm{d}) \\
+7.04 \times \text { crude protein }(\mathrm{kg} / \mathrm{d})
\end{gathered}
$$

Energy-corrected milk is milk yield adjusted to $3.5 \%$ fat and 3.2\% protein content (Tyrrell and Reid, 1965). Early lactation yield was represented by summit ECM, which was the average of the highest 2 daily values from the first 3 milk recording days. Energy-corrected milk was grouped into 11 classes $(<15,15$ to 19,20 to 24,25 to 29,30 to 34,35 to 39,40 to 44,45 to 49,50 to 54,55 to 59 , and $>59 \mathrm{~kg}$ ).

The model adjusted for the effect of stage of lactation by using 11 classes of DIM at first insemination $(<50$, 50 to 59,60 to 69,70 to 79,80 to 89,90 to 99,100 to 109,110 to 119,120 to 129,130 to 139 , and $>139$ d). Differences in daughter ages were considered by the inclusion of 6 parity groups (1, 2, 3, 4, 5, and $>5$ ).

The ERCR-S were animal effects for sires and were solutions $\times 100$.

Model 2 for DIM at first mating. Estimates of sires' EBV for differences of daughters from herdmates for DIM1-S were computed using a model that was similar to the one used for ERCR-S except that DIM1 was the dependent random effect, not a fixed effect. Additionally, the mating bull was not included in the model. The DIM1-S estimates were the animal solutions.

Solutions for models 1 and 2 were computed by a program (Misztal, 1994) that incorporates iteration-ondata using second-order Jacobi.

Model 3 for mating bull fertility. Although the above-described model 1 computes estimates of mating bull fertility for sires, an independent measure of mating bull fertility was used to determine the relationship between a bull's fertility as a mate and the fertility of his daughters. This independent model avoids any partwhole relationships with sire fertility estimates that would have been introduced by the previous model.

Using the methods and model described by Clay and McDaniel (2001), estimated relative conception rate of mating bull or the difference from average AI mating bull of herdmates for rate of nonreturn in $70 \mathrm{~d}$ for first AI mating (ERCR-MB) was computed for 3208 bulls with a minimum of 50 first matings during the period of 1995 through 1997 . These computations used 1,423,728 records from 1,154,265 cows in 305,833 herd-year-sea- 
Table 2. Estimates of heritability $\left(\mathrm{h}^{2}\right)$, repeatability $(\mathrm{R})$, and residual variance for $\mathrm{NR} 70^{1}$ and DIM1. ${ }^{2}$

\begin{tabular}{llllllll}
\hline & \multicolumn{3}{c}{ NR70 } & & \multicolumn{3}{c}{ DIM1 } \\
\cline { 2 - 4 } \cline { 6 - 8 } Region & $\mathrm{h}^{2}$ & $\mathrm{R}$ & $\begin{array}{c}\text { Residual } \\
\text { variance }\end{array}$ & & $\mathrm{h}^{2}$ & $\mathrm{R}$ & $\begin{array}{l}\text { Residual } \\
\text { variance }\end{array}$ \\
\hline National US 1 & 0.019 & 0.071 & 0.240 & & 0.066 & 0.164 & 1157 \\
National US 2 & 0.016 & 0.061 & 0.218 & & 0.044 & 0.111 & 1290 \\
Southeastern US 1 & 0.015 & 0.060 & 0.211 & & 0.032 & 0.099 & 1199 \\
Southeastern US 2 & 0.015 & 0.063 & 0.217 & & 0.026 & 0.085 & 1058 \\
\hline
\end{tabular}

${ }^{1} \mathrm{NR} 70=$ Nonreturn in $70 \mathrm{~d}$ to first AI mating.

${ }^{2}$ DIM1 = Days in milk at first AI mating.

sons. Because cows included in this data set were not required to have unique sire or dam identities, more records were available than were in the data set used to estimate breeding values for sires, potentially resulting in measures with higher accuracy.

\section{RESULTS AND DISCUSSION}

Table 2 shows the estimates for heritabilities, repeatabilities, and the residual variances for NR70 and DIM1 for each data set. Heritabilities and repeatabilities were low but similar across sets. Although heritabilities and repeatabilities were somewhat higher for National US 1 than for other sets, these differences were probably due to random differences in the data sets. Overall, the values were somewhat lower but similar to corresponding values in the literature for linear models (Ron et al., 1984; Hermas et al., 1987; Faust et al., 1989; Weller and Ron, 1992; Boichard and Manfredi, 1994). For NR70, the impact of regions seemed to be negligible, which indicates that, within the available area, the heritabilities can be used for the computation of fertility estimates without concern for herd location.

The heritability estimates for DIM1 were between 0.026 and 0.066 , which confirms estimates from earlier studies (Berger et al., 1981; Hansen et al., 1983; Seykora and McDaniel, 1983; Faust et al., 1989; Hayes et al., 1992; Marti and Funk, 1994; Dematawewa and Berger, 1998). Repeatability estimates ranged from 0.085 to 0.164 and were similar to estimates in the literature (Hansen et al., 1983; Hayes et al., 1992; Dematawewa and Berger, 1998). Because the computational method does not produce standard errors, estimates of relative accuracy were not available. As expected, heritabilities and repeatabilities for DIM1 were higher than estimates for NR70. Values for both heritability and repeatability appeared generally higher for both national data sets than for the data sets from the southeastern region. The values may have been lower in the southeast because, for the seasons from late spring through midfall, many producers in the southeast do not attempt to breed cows because of historically low success resulting from high heat and humidity. This practice could extend the days to first breeding for lactations begun in the spring, which could, in turn, reduce repeatabilities. It is not clear why residual variances for the southeastern data sets were not larger than residual variances for the national data sets unless it is because the inclusion of herd-year-month of breeding in the model effectively accounted for the changes in breeding practices in the summer.

The complete data set was used to compute solutions for DIM1-S and ERCR-S for 1004 bulls, each with a minimum of 30 daughters in 1995 through 1997. Assumed heritabilities and repeatabilities were based upon midrange values of computed estimates and were 0.04 and 0.09 for DIM1-S and 0.02 and 0.05 for ERCR$\mathrm{S}$. The standard deviations and ranges for the resulting DIM1-S were $8.8 \mathrm{~d}$ and -30.4 to $32.6 \mathrm{~d}$, and for ERCR$\mathrm{S}$, they were $3.9 \%$ and -14.3 to $16.2 \%$.

Solutions showing the relationships between the fertility traits of DIM1 and NR70 with fixed effects are summarized in Table 3. Higher early lactation yield, as represented by ECM, was associated with increased days to first mating and lower nonreturn rate, which agrees with earlier studies (Matsoukas and Fairchild, 1975; Berger et al., 1981; Faust et al., 1989). The relative effect of ECM on days to first mating increased at an increasing rate to the highest class of ECM. Although the aberrance of the class of lowest ECM could be attributed to very few numbers, it possibly is due to cows not rebreeding as soon because of sickness. The impact of any transition cow problems probably affects reproductive responsiveness as much as it affects milk production.

Age effects, as represented by parity, indicate that younger cows were mated later in lactation than older cows, but the nonreturn rates of first-parity cows were somewhat higher than those of older cows, in agreement with earlier research (Berger et al., 1981; Hillers et al., 1984). Breeding cows earlier than $80 \mathrm{~d}$ was associated with lower nonreturn rates, whereas nonreturn rates increased as the days to first mating increased to more than $139 \mathrm{~d}$. These differences are similar to results of 
Table 3. Estimated differences among solutions of DIM1 ${ }^{1}$ (days) and $\mathrm{NR} 70^{2}$ (percent) for $\mathrm{ECM},{ }^{3}$ parity, and DIM1.

\begin{tabular}{|c|c|c|c|c|c|c|c|}
\hline \multicolumn{3}{|c|}{ ECM (Kg) } & \multicolumn{3}{|c|}{ Parity } & \multicolumn{2}{|c|}{ DIM1 } \\
\hline Class & DIM1 & NR70 & Class & DIM1 & NR70 & Class & NR70 \\
\hline$<15$ & -0.81 & 2.79 & 1 & 4.89 & 1.32 & $<50$ & -5.31 \\
\hline 15 to 19 & -3.97 & 1.71 & 2 & -1.22 & -0.40 & 50 to 59 & -1.86 \\
\hline 20 to 24 & -3.93 & 1.75 & 3 & -2.95 & -0.68 & 60 to 69 & -1.02 \\
\hline 25 to 29 & -3.23 & 0.88 & 4 & -3.11 & -1.26 & 70 to 79 & -0.04 \\
\hline 30 to 34 & -1.61 & 0.43 & 5 & -3.06 & -2.55 & 80 to 89 & 0.54 \\
\hline 35 to 39 & 0.02 & -0.05 & $>5$ & -2.26 & -3.99 & 90 to 99 & 0.81 \\
\hline 40 to 44 & 1.69 & -0.86 & & & & 100 to 109 & 1.06 \\
\hline 45 to 49 & 3.02 & -1.67 & & & & 110 to 119 & 1.91 \\
\hline 50 to 54 & 4.81 & -2.43 & & & & 120 to 129 & 1.59 \\
\hline 55 to 59 & 5.97 & -2.97 & & & & 130 to 139 & 1.44 \\
\hline$>59$ & 8.26 & -4.54 & & & & $>139$ & 2.96 \\
\hline
\end{tabular}

${ }^{1} \mathrm{DIM} 1$ = Days in milk at first AI mating.

${ }^{2} \mathrm{NR} 70=$ Nonreturn in $70 \mathrm{~d}$ to first AI mating.

${ }^{3} \mathrm{ECM}=$ Summit daily early-lactation energy-corrected-milk.

other studies (Berger et al., 1981; Hillers et al., 1984; Faust et al., 1989).

The standard deviation and range for ERCR-MB computed from the independent data set were 3.8 and -18.9 to 13.2 , and they were similar to reported values (Clay and McDaniel, 2001).

In an effort to facilitate focus on bulls with fertility traits computed from sufficient numbers to produce more accurate estimates, a subset included 213 bulls with 200 first matings and 100 daughters with reproductive values in the period studied. The standard deviations and ranges of breeding values of this subset of bulls are summarized in Table 4 and, as expected, were smaller than those for the complete data set. Although a significant correlation between the fertility of a bull and the fertility of his daughters might be expected, the correlation of ERCR-S with ERCR-MB was small, whereas the correlation of DIM1-S with ERCR-MB was higher but still not highly significant. These 2 findings indicate that bulls that are the most fertile as mating

Table 4. Standard deviations and ranges of breeding values for daughter groups plus correlations with solutions from sire as mating bull for a subset of 213 sires restricted to a minimum of 100 daughters and 200 matings.

\begin{tabular}{llll}
\hline Trait & SD & Range & $\begin{array}{l}\text { Correlation with } \\
\text { ERCR-MB }^{1}\end{array}$ \\
\hline ERCR-S & 3.8 & -11 to 10 & 0.07 \\
DIM1-S $^{3}$ & 9.1 & -31 to 18 & $-0.12^{\mathrm{a}}$ \\
\hline
\end{tabular}

${ }^{\mathrm{a}} P<0.08$.

${ }^{1} \mathrm{ERCR}-\mathrm{MB}=$ Estimated relative conception rate of mating bull or the difference from average AI mating bull of herdmates for rate of nonreturn in $70 \mathrm{~d}$ for first AI mating.

${ }^{2}$ ERCR-S = Estimated relative conception rate of sire or EBV for nonreturn in $70 \mathrm{~d}$ for first AI mating.

${ }^{3}$ DIM1-S = EBV of sire for days in milk at first AI mating. bulls do not necessarily sire cows that are the most fertile, and they also indicate that different genes affect the 2 traits.

Most correlations (Table 5) between our measures of reproductive traits and PTA produced by the USDA in August 1998 were not significant. Exceptions were correlations of PTA-PL with ERCR-S $(P<0.05)$ and with DIM1-S $(P<0.01)$. A longer life can be expected from both cows that show heat earlier and cows with higher nonreturn rates. These low correlations indicate that, although the response to selection will be in the proper economic direction with improvements in PTAPL, substantial improvements in reproductive traits will not occur unless the traits receive specific selection pressure. Additionally, the lack of correlation between sire effects for production traits and fertility supports earlier conclusions (Lucy, 2001) that production has had only a minor impact on recent historically declining fertility.

After adjusting for PTA-Milk and PTA-SCS, there was a modest (0.29) partial correlation between DIM1-

Table 5. Correlations of PTA with breeding values for reproduction of daughters.

\begin{tabular}{lcc}
\hline & ERCR-S & DIM1-S \\
\hline ERCR-S $^{1}$ & $\ldots$ & 0.11 \\
PTA-Milk & 0.01 & 0.01 \\
PTA-Protein & -0.02 & $-0.13^{\mathrm{a}}$ \\
PTA-Fat & 0.06 & 0.03 \\
PTA-Productive life & $0.18^{* * *}$ & $-0.33^{* * *}$ \\
PTA-SCS & $-0.13^{\mathrm{a}}$ & 0.02 \\
\hline
\end{tabular}

${ }^{\text {a } P}<0.10$

${ }^{1}$ ERCR-S = Estimated relative conception rate of sire or EBV for rate of nonreturn in $70 \mathrm{~d}$ for first AI mating. DIM1-S = EBV of sire for days in milk at first AI mating.

$* * *=P<0.001$. 
Table 6. Independent effects of breeding values for reproduction on PTA-Productive Life after adjusting for PTA-Milk and PTA-SCS.

\begin{tabular}{|c|c|c|}
\hline & $\begin{array}{l}\text { Partial } \\
\text { R-square }\end{array}$ & $\begin{array}{l}\text { Partial } \\
\text { R }\end{array}$ \\
\hline DIM1-S ${ }^{1}$ & 0.087 & 0.29 \\
\hline ERCR-S ${ }^{2}$ & 0.024 & 0.15 \\
\hline ERCR-MB ${ }^{3}$ of daughter's sire & 0.017 & 0.13 \\
\hline DIM1-S and ERCR-S & 0.116 & 0.34 \\
\hline Predicted calving interval index & 0.102 & 0.32 \\
\hline
\end{tabular}

${ }^{1}$ DIM1-S = EBV value of sire for days in milk at first AI mating.

${ }^{2}$ ERCR-S = Estimated relative conception rate of sire or EBV for nonreturn in $70 \mathrm{~d}$ for first AI mating.

${ }^{3} \mathrm{ERCR}-\mathrm{MB}=$ Estimated relative conception rate of mating bull or the difference from average AI mating bull of herdmates for rate of nonreturn in $70 \mathrm{~d}$ for first $\mathrm{AI}$ mating.

S and PTA-PL (Table 6). The relationship of PTA-PL with sire's nonreturn rate (ERCR-S) was weaker (0.15). When both traits were considered together, the partial correlation increased modestly from 0.29 to 0.34 . DIM1$\mathrm{S}$ and ERCR-S were associated with about $12 \%$ of the variance in PTA-PL.

The CI Index was associated with about $10 \%$ of the variance in PTA-PL, less than a 2-point reduction from the 2 individual sire fertility traits considered simultaneously.

Fertility traits for several extensively used bulls (more than 1000 daughters each) are illustrated in Table 7 in order by DIM1-S. Daughters of bulls at the top of the list are expected to be AI bred earlier in lactation relative to daughters of other bulls on the list. For example, daughters of bull 1 are expected to be bred for the first time $9 \mathrm{~d}$ earlier in the lactation than herdmates. Correspondingly, daughters of bull 14 are expected to be AI bred for the first time $20 \mathrm{~d}$ later than herdmates. Values in Table 7 illustrate the lack of association between ERCR-S and DIM1-S. Although daughters of bull 11 are expected to require an additional week before first AI breeding, the chance of the daughters being rebred within $70 \mathrm{~d}$ is 10 points less than herdmates.
As illustrated by bulls 1 and 3, daughters of some bulls were bred earlier in lactation, when compared with daughters of other bulls on the list, indicating higher fertility. However, daughters of these same 2 bulls are also expected to have a greater chance of being rebred within $70 \mathrm{~d}$, indicating lower fertility. Because the CI Index utilizes both traits, it may enable both traits to be appropriately considered in selection decisions. In Table 7, bull 3 is an example of how a large negative value for ERCR-S can markedly reduce the expected advantage of a large negative DIM1-S when computing expected days of CI.

\section{CONCLUSIONS}

The heritabilities for DIM1 and NR70 are sufficient to yield accurate estimates of sire EBV for large daughter groups, and some response to selection can be expected if estimates are based on large numbers of daughters. Since DIM1-S and ERCR-S were significantly correlated with and can account for significant variability in PTA-PL, both traits should be important to producers. When CI Index was adopted to use DIM1-S and ERCR$\mathrm{S}$ to predict differences in calving interval, it was found to be correlated with PTA-PL almost to the same extent as the 2 traits considered together. It seems that the CI Index provides an easily interpreted measure that can help identify bulls that will sire daughters with shorter calving intervals, a primary fertility trait.

Correlations between a bull's fertility as a mating bull and as a sire of daughters were near 0 , which means that at least some of the genes that affect a bull's fertility and the fertility of his daughters are different.

\section{ACKNOWLEDGMENTS}

This research was partially supported by producers whose DHIA records are processed by Dairy Records Management Systems and by a grant from the North

Table 7. Fertility EBV for daughters of some widely used sires.

\begin{tabular}{|c|c|c|c|c|c|c|c|}
\hline Bull & DIM1-S ${ }^{1}$ & ERCR-S ${ }^{2}$ & $\begin{array}{l}\text { Predicted } \\
\text { CI Index }\end{array}$ & Bull & DIM1-S & ERCR-S & $\begin{array}{l}\text { Predicted } \\
\text { CI Index }\end{array}$ \\
\hline 1 & -9 & -5 & -7.0 & 8 & 7 & 0 & 7.0 \\
\hline 2 & -8 & 3 & -9.2 & 9 & 7 & 1 & 6.6 \\
\hline 3 & -8 & -11 & -3.6 & 10 & 8 & -2 & 8.8 \\
\hline 4 & -4 & 2 & -4.8 & 11 & 9 & 10 & 5.0 \\
\hline 5 & 1 & -2 & 1.8 & 12 & 18 & 4 & 16.4 \\
\hline 6 & 2 & -5 & 4.0 & 13 & 19 & 3 & 17.8 \\
\hline 7 & 3 & -4 & 4.6 & 14 & 20 & 0 & 20.0 \\
\hline
\end{tabular}

${ }^{1}$ DIM1-S = EBV of sire for days in milk at first AI mating.

${ }^{2} \mathrm{ERCR}-\mathrm{S}=$ Estimated relative conception rate of sire or EBV for nonreturn in $70 \mathrm{~d}$ for first $\mathrm{AI}$ mating.

${ }^{3}$ Predicted CI (calving Interval) Index (days) = DIM1-S (days) $-0.4 \times$ ERCR-S $(\%)$. 
Carolina Dairy Foundation. The authors appreciate the assistance of 2 anonymous reviewers.

\section{REFERENCES}

Badinga, L., R. J. Collier, W. W. Thatcher, and C. J. Wilcox. 1985. Effects of climatic and management factors on conception rate of dairy cattle in subtropical environment. J. Dairy Sci. 68:78-85.

Berger, P. J., R. D. Shanks, A. E. Freeman, and R. C. Laben. 1981. Genetic aspects of milk yield and reproductive performance. J. Dairy Sci. 64:114-122.

Boichard, D., and E. Manfredi. 1994. Genetic analysis of conception rate in French Holstein dairy cattle. Acta Agric. Scand., Sect. A 44:138-145.

Butler, W. R. 1998. Review: effect of protein nutrition on ovarian and uterine physiology in dairy cattle. J. Dairy Sci. 81:2533-2539.

Clay, J. S., and B. T. McDaniel. 2001. Computing mating bull fertility from DHI non-return data. J. Dairy Sci. 84:1238-1245.

de Jong, G. 1997. Index for daughter's fertility in the Netherlands. Pages 102-105 in Proc. Int. Workshop on Genetic Improvement of Functional Traits in Cattle, Interbull Bull. No. 18, 1998.

Dematawewa, C. M. B., and P. J. Berger. 1998. Genetic and phenotypic parameters for 305-day yield, fertility, and survival in Holsteins. J. Dairy Sci. 81:2700-2709.

Faust, M. A., B. T. McDaniel, and O. W. Robison. 1989. Genetics of reproduction in primiparous Holsteins. J. Dairy Sci. 72:194-201.

Guazdauskas, F. C., W. W. Thatcher, and C. J. Wilcox. 1973. Physiological, environmental, and hormonal factors at insemination, which may affect conception. J. Dairy Sci. 57:873-877.

Hansen, L. B., A. E. Freeman, and P. J. Berger. 1983. Yield and fertility relationships in dairy cattle. J. Dairy Sci. 66:293-305.

Hayes, J. F., R. I. Cue, and H. G. Monardes. 1992. Estimates of repeatability of reproductive measures in Canadian Holsteins. J. Dairy Sci. 75:1701-1706.

Hermas, S. A., C. M. Young, and J. W. Rust. 1987. Genetic relationships and additive genetic variation of productive and reproductive traits in Guernsey dairy cattle. J. Dairy Sci. 70:1252-1257.

Hillers, J. K., P. L. Senger, R. L. Darlington, and W. N. Fleming. 1984. Effects of production, age of cow, days dry, and days open on conception to first service in large commercial dairy herds. J. Dairy Sci. 67:861-867.

Lucy, M. C. 2001. Reproductive loss in high-producing dairy cattle: Where will it end? J. Dairy Sci. 84:1277-1293.

Marti, C. F., and D. A. Funk. 1994. Relationship between production and days open at different levels of herd production. J. Dairy Sci. 77:1682-1690.

Matsoukas, J., and T. P. Fairchild. 1975. Effects of various factors on reproductive efficiency. J. Dairy Sci. 58:540-544.

Misztal, I. 1990. Restricted maximum likelihood estimation of variance components in animal model using sparse matrix inversion and a supercomputer. J. Dairy Sci. 73:163-172.

Misztal, I. 1994. Comparison of software packages in animal breeding. Proc. 5th World Congr. Genetics. Appl. Livest. Prod. Sci. 22:3-10.

Roman-Ponce, H., W. W. Thatcher, D. E. Buffington, C. L. Wilcox, and H. H. Van Horn. 1977. Physiological and production responses of dairy cattle to a shade structure in a subtropical environment. J. Dairy Sci. 60:424-430.

Ron, M., R. Bar-Anan, and G. R. Wiggans. 1984. Factors affecting conception rate of Israeli Holstein cattle. J. Dairy Sci. 67:854-860.

SAS User's Guide: Statistics, Version 6 Edition. 1990. SAS Inst., Inc. Cary, NC.

Seykora, A. J., and B. T. McDaniel. 1983. Heritabilities and correlations of lactation yields and fertility for Holsteins. J. Dairy Sci. 66:1486-1493

Silvia, W. J. 1998. Changes in reproductive performance of Holstein dairy cows in Kentucky from 1972 to 1996. J. Dairy Sci. 81(Suppl.1):244. (Abstr.)

Thatcher, W. W. 1974. Effects of season, climate, and temperature on reproduction and lactation. J. Dairy Sci. 57:360-368.

Tyrrell, H. F., and J. T. Reid. 1965. Prediction of the energy value of cow's milk. J. Dairy Sci. 48:1215-1223.

Weller, J. I., and M. Ron. 1992. Genetic analysis of fertility traits in Israeli Holsteins by linear and threshold models. J. Dairy Sci. 75:2541-2548

Wolfe, L. K., and D. E. Monty, Jr. 1974. Physiologic response to intense summer heat and its effect on the estrous cycle of nonlactating and lactating Holstein-Friesian cows in Arizona. Am. J. Vet. Res. 35:87-92.

VanRaden, P. M., and G. R. Wiggans. 1995. Productive life evaluations: Calculation, accuracy, and economic value. J. Dairy Sci. 78:631-638. 